Journal of Engineering and Applied Sciences 14 (18): 6769-6776, 2019

ISSN: 1816-949X

(C) Medwell Journals, 2019

\title{
Improving the Flexural Capacity of Reinforced Concrete One-Way Slabs by Different Techniques
}

\author{
Mohammed Mahmood, Wissam D. Salman and Huda Mubarak \\ Department of Civil Engineering, University of Diyala, Baqubah, Iraq, \\ mohammed.mahmood@uodiyal.edu.iq
}

\begin{abstract}
This study presents the experimental results, observations and evaluation from an investigation looking into the effect of different strengthening techniques on the behaviour of one-way reinforced concrete slab. The research aims to propose recommendations for the best strengthening method to achieve the optimum performance of one-way slabs. Results indicate that the stiffness of the strengthening layer must not be more than $1 / 38$ of the stiffness of the strengthened element to avoid brittle failure. Two modes of failure were observed: flexural ductile failure and brittle shear failure in addition to debonding of CFRP layers. The improvement in the initial cracking load is always higher than that in the ultimate load. To achieve the optimum performance of the slab in terms of strength, stiffness and ductility, the width of the steel plate should be equal to the width of the slab and the thickness of the steel plate must not be more than $t / 64$ where $t$ is the slab thickness. It is recommended to not strengthen one-way reinforced concrete slabs by ferrocement as the specimens strengthened by ferrocement did not show noticeable improvement in the strength and stiffness.
\end{abstract}

Key words: Strengthening, one-way slab, overlaying concrete, ferrocement, CFRP, steel plates

\section{INTRODUCTION}

Strengthening of reinforced concrete structural elements with numerous techniques and materials has received significant research attention in recent decades (Wang and Tan, 2002; Erki and Heffernan, 1995; Loreto et al., 2013; Anil et al., 2013; El Maaddawy and Soudki, 2008; Smith et al., 2011; Correia et al., 2017; Kim et al., 2013; Smith and Kim, 2009; Yang et al., 2018; Tank and Modhera, 2017). For example, FRP (Fathelbab et al., 2014), steel plates (Ngidi and Dundu, 2018), ferrocement (Shaheen and Abusafa, 2017), near surface mounted steel rebars (Ali and Yehia, 2016) and overlaying concrete (Fernandes et al., 2017). They can be plated into the slabs using various techniques such as epoxy and shear connectors. Julio et al. (2010) performed experimental and numerical study to evaluate the accuracy of the codes in overlay strengthening. They stated that the exciting design equations are overestimating the shear strength at the interface for low reinforcement ratios whereas for high reinforcement ratios the codes equations are too conservative. Al-Kubaisy and Jumaat (2000) investigated the flexural behaviour of reinforced concrete slabs with ferrocement layer at the tension cover. The study reported that the use of ferrocement could slightly improve the slab ultimate strength and the first cracking load. However, the improvement was higher with increase of the reinforcement and thickness of the ferrocement layer. Alam et al. (2018) proposed a comprehensive strengthening technique to eliminate early failures of reinforced concrete slabs strengthened using steel plates with end anchor and embedded connectors. The researchers claimed that the proposed technique prevents end peeling and shear failure. Theoretical models for predicting the slab capacity was also suggested. The efficiency of using fastener in attaching FRP to reinforced concrete beams was investigated by Martin and Lamanna (2008). The study stated that the proposed technique could improve the flexural capacity of the strengthened beams by up to $39 \%$ without affecting the beam ductility. Hor et al. (2017) investigated the behaviour of composite reinforced concrete slabs strengthened with ultra-high performance concrete. The study considered two series: rehabilitations which include the use of ultra-high performance concrete as patch material for repairing deteriorated concrete structures and overlying of the slabs with ultra-high performance concrete. For rehabilitations series, it was reported that there was clear reduction in the diagonal cracks and increasing of the flexural cracks (failure changed from brittle to ductile). In the overlying series, it was stated that the overlay concrete delays development of shear cracking and

Corresponding Author: Mohammed Mahmood, Department of Civil Engineering, University of Diyala, Baqubah, Iraq, mohammed.mahmood@uodiyal.edu.iq 
improve the energy abolition ability. The evident presented in the literatures reveals that each strengthening technique has number of advantages and disadvantages. For safety, practicality and economy reasons there is a need for suggesting recommendations for each strengthening techniques to achieve the optimum performance. Therefore, this research aims at investigating and evaluating the performance of strengthened one-way reinforced concrete slabs and propose the recommendations to optimize the performance of one-way slab in each strengthening method.

\section{MATERIALS AND METHODS}

Experimental programme and instrumentations: To evaluate the improvement of different strengthening techniques on the behaviour of one-way slab, nineteen specimens were tested this research. The specimens were constructed to simulate one-way solid reinforced concrete slabs. Details of the specimens are shown in Fig. 1. All specimens were $1050 \mathrm{~mm}$ length, $400 \mathrm{~mm}$ width and $80 \mathrm{~mm}$ thickness. They were reinforced with $3 \Phi 12$ steel bars in the longitudinal direction and $7 \Phi 12$ steel bars in the transverse direction. After casting, the specimens were covered with polythene sheets for $24 \mathrm{~h}$. Then they were demoulded and placed in curing water for 27 days. The strengthening process started after completing the curing. The experimental programme was divided into four first group was strengthened with overlaying concrete, the second was strengthened with ferrocement, the third was strengthened with CFRP and the fourth group was strengthened with steel plates. Prior to strengthening, the concrete surface was roughened using a grinding machine and the resulted surface was cleaned from dust using a vacuum cleaner (Fig. 2).

First group; Overlaying concrete: Overlaying Concrete (OC) was added to the top of the strengthened slab (at the compression side). It was reinforced with welded wire mesh $50 \times 50 \mathrm{~mm}$ hole size and $4 \mathrm{~mm}$ bar diameter. Four technics of bonding were used to attach the $\mathrm{OC}$ to the specimens: SikaDur 32 (SD) Ordinary Portland Cement (OPC), Shear Connectors (SC) and without any binder. M8 bolts were used as shear connectors. They were inserted in predrilled holes and distributed in two rows at $150 \mathrm{~mm}$ center to center spacing (Fig. 3). The OC was cured with water for 28 days after casting for all specimens. The details of the tested specimens are presented in Table 1.

Second group; Ferrocement: In this group, a layer of ferrocement mortar was used as a strengthening layer (Fig. 4). The details of the ferrocement mix are: 1-2 cement to sand ratio, $\mathrm{W} / \mathrm{C}=0.47$, flow $=170 \mathrm{~mm}$ and compressive strength of $30 \mathrm{MPa}$. The surface of the slab was grinded before installation the ferrocement layer to increase bonding. Similar to the previous group (OC group), M8 bolts were used in the same distribution. The varying
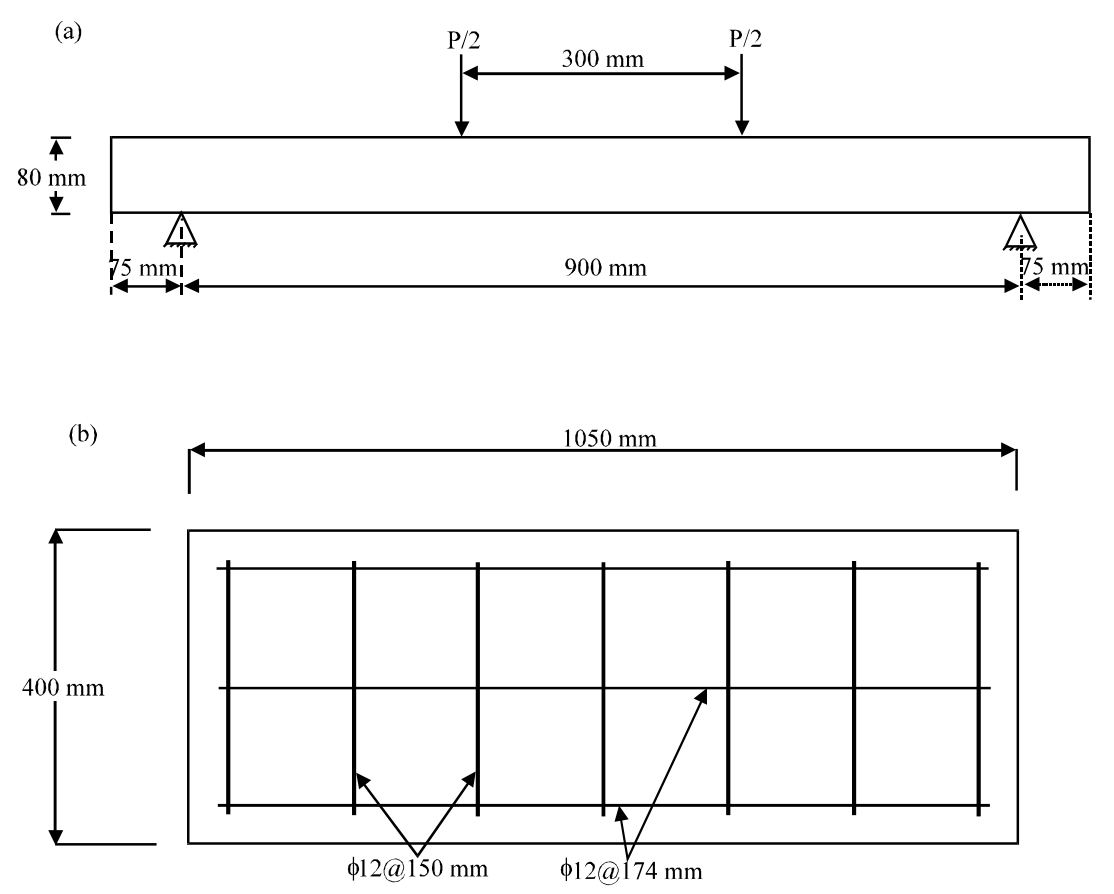

Fig. 1: Details of the specimens: a) Geometry of specimens and b) Reinforcement of specimens 
(a)

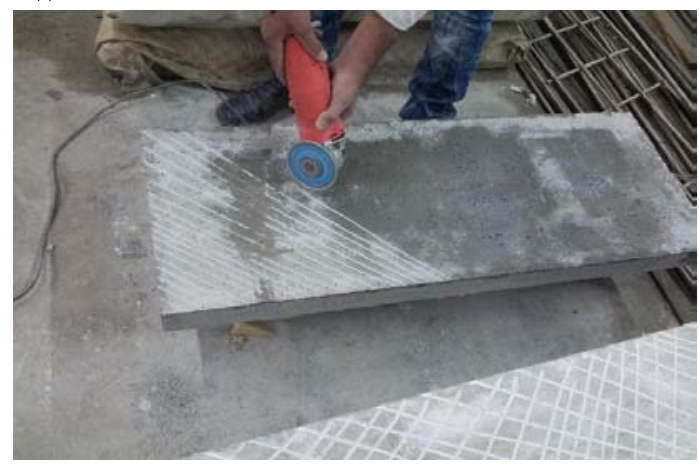

(b)

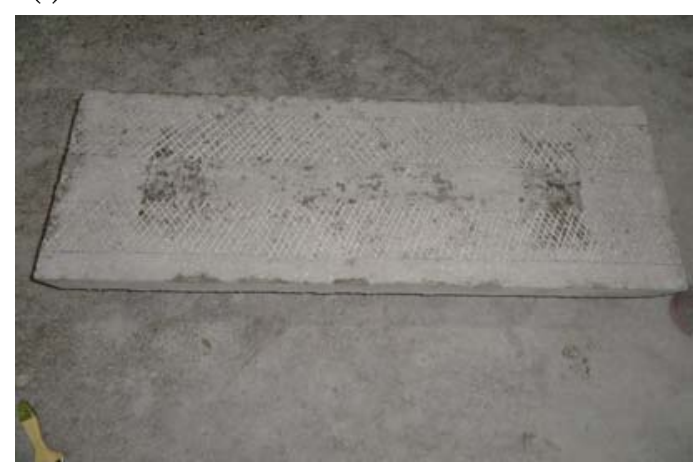

Fig. $2 \mathrm{a}, \mathrm{b}$ ): Surface preparation for the strengthened specimens

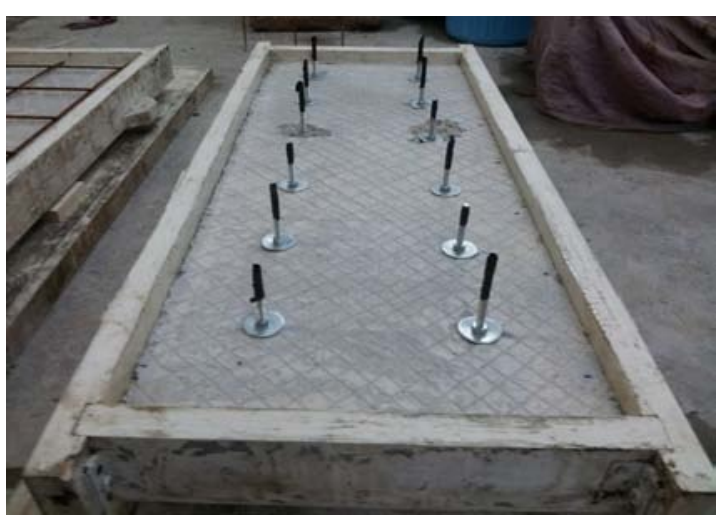

Fig. 3: Shear connector's distribution

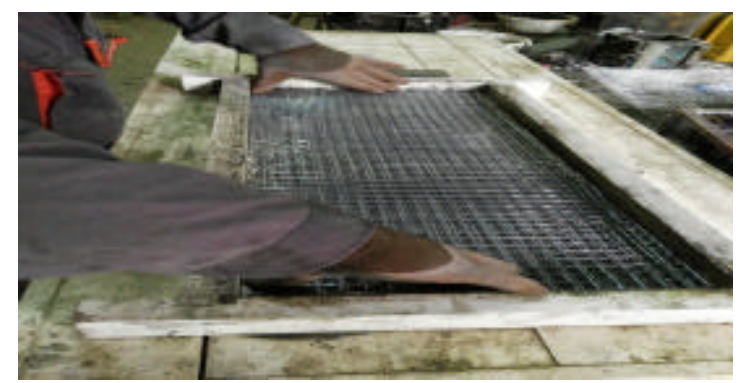

Fig. 4: Wire mesh installation in ferrocement layer

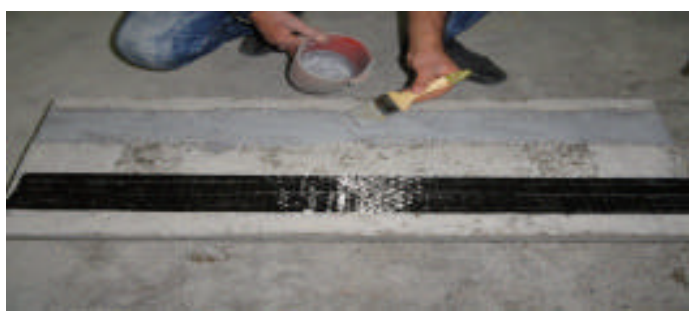

Fig. 5: Placement of CFRP sheets

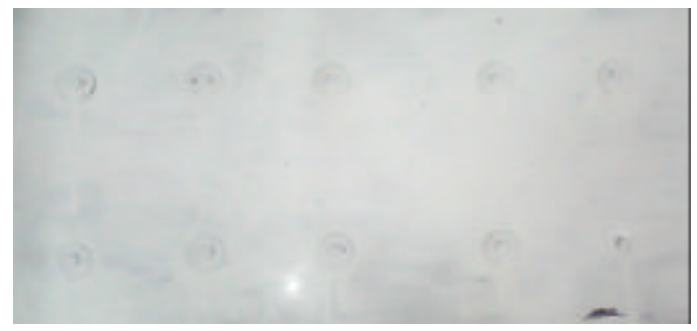

Fig. 6: Strengthening using steel plates

parameters in this group were thickness of the ferrocement layer ( 20 and $40 \mathrm{~mm}$ ), the number of layers of wire mesh ( 2 and 4 layers). The wire mesh openings size is $15 \times 15 \mathrm{~mm}$ and the wire diameter is $0.6 \mathrm{~mm}$. The ferrocement layer was reinforced by 0 and $1 \%$ steel fiber (weight ratio). The diameter aspect ratio and the density of steel fiber were $12,0.2 \mathrm{~mm}, 60$ and $7800 \mathrm{~kg} / \mathrm{m}^{3}$, respectively. The details of tested specimen of this group are presented in Table 1.

Third group; CFRP: CFRP fabric sheets were placed over a thin layer of resin and impregnated with resin using a plastic roller. Then a resin layer of $0.5 \mathrm{~kg} / \mathrm{m}^{2}$ was spread over the surface of the fabric sheets (Fig. 5). The effect of changing the width and the number of layers of CFRP were investigated in this group. All the details of the tested specimens are presented in Table 1.

Fourth group; Steel plates: A36 steel plates were used to enhance the specimen's resistance. They were attached at the tension side of the specimens using M8 bolts (Fig. 6). The bolts were distributed in two rows at $210 \mathrm{~mm}$ center to center spacing. The investigated parameters here were: the thickness and the width of the steel plates (Table 1).

All specimens were tested at the age of 30 days. They were subjected to four points bending as shown in Fig. 7. Before the test, the specimens were painted with white colour to highlight the cracks. After the specimen is placed in position, they were loaded up to failure using 


\begin{tabular}{|c|c|c|c|c|c|c|c|c|c|c|c|c|}
\hline Specimens & $\begin{array}{l}\text { Types of } \\
\text { strengthening }\end{array}$ & $\begin{array}{l}\text { Position of } \\
\text { strengthening }\end{array}$ & $\begin{array}{l}\text { Thickness } \\
\text { of } \mathrm{O} . \mathrm{C} \\
(\mathrm{mm})\end{array}$ & $\begin{array}{l}\text { Comp. } \\
\text { strength } \\
\text { of slabs } \\
\left(\mathbb{N} / \mathrm{mm}^{2}\right)\end{array}$ & $\begin{array}{l}\text { Comp. } \\
\text { strength } \\
\text { of } O . C \\
\left(\mathrm{~N} / \mathrm{mm}^{2}\right)\end{array}$ & $\begin{array}{l}\text { Bonding } \\
\text { materials }\end{array}$ & $\begin{array}{l}\text { Ferrocement } \\
\text { mix }\end{array}$ & $\begin{array}{l}\text { No. of } \\
\text { ferrocement } \\
\text { mesh layers }\end{array}$ & $\begin{array}{l}\text { Thickness of } \\
\text { ferrocement } \\
(\mathrm{mm})\end{array}$ & $\begin{array}{l}\text { No. of } \\
\text { CFRP } \\
\text { or St. P1 }\end{array}$ & $\begin{array}{l}\text { Width of } \\
\text { CFRP or } \\
\text { St. P1. } \\
\text { (mm) }\end{array}$ & $\begin{array}{l}\text { Thickness } \\
\text { of St. Pl. } \\
\text { (mm) }\end{array}$ \\
\hline \multicolumn{13}{|c|}{ First group: Overlaying Concrete } \\
\hline $\mathrm{S}_{0}$ & - & - & - & 43 & - & - & - & - & - & - & - & - \\
\hline O2OSDS40 & O.C & Top & 20 & 43 & 40 & SD32 & - & - & - & - & - & - \\
\hline O40SDS40 & O.C & Top & 40 & 43 & 40 & SD32 & - & - & - & - & - & - \\
\hline O20SDS 80 & O.C & Top & 20 & 43 & 80 & SD 32 & - & - & - & - & - & - \\
\hline O20WS40 & O.C & Top & 20 & 43 & 40 & Without & - & - & - & - & - & - \\
\hline O20SCS40 & O.C & Top & 20 & 43 & 40 & SC. & - & - & - & - & - & - \\
\hline O20COPCS40 & $\mathrm{O} . \mathrm{C}$ & Top & 20 & 43 & 40 & $\mathrm{OPC}$ & - & - & - & - & - & - \\
\hline \multicolumn{13}{|c|}{ Second group; Ferrocement } \\
\hline F2-20-0 & $\mathrm{F}$ & Bot. & - & 43 & - & - & F1 & 2 & 20 & - & - & - \\
\hline F4-20-0 & $\mathrm{F}$ & Bot. & - & 43 & - & - & $\mathrm{F} 1$ & 4 & 20 & - & - & - \\
\hline F2-40-0 & $\mathrm{F}$ & Bot. & - & 43 & - & - & F1 & 2 & 40 & - & - & - \\
\hline F2-20-1 & $\mathrm{F}$ & Bot. & - & 43 & - & - & F2 & 2 & 20 & - & - & - \\
\hline F4-20-1 & $\mathrm{F}$ & Bot. & - & 43 & - & - & F2 & 4 & 20 & - & - & - \\
\hline F2-40-1 & $\mathrm{F}$ & Bot. & - & 43 & - & - & F2 & 2 & 40 & - & - & - \\
\hline \multicolumn{13}{|c|}{ Third group; CFRP } \\
\hline $\mathrm{C} 2-50$ & CFRP & Bot. & - & 43 & - & SD32 & - & - & - & 2 & 50 & - \\
\hline C1-100 & CFRP & Bot. & - & 43 & - & SD32 & - & - & - & 1 & 100 & - \\
\hline $\mathrm{C} 2-100$ & CFRP & Bot. & - & 43 & - & $\mathrm{SD} 32$ & - & - & - & 2 & 100 & - \\
\hline \multicolumn{13}{|c|}{ Fourth group; ateel plates } \\
\hline $\mathrm{S} 1-200-1.25$ & St. P1. & Bot. & - & 43 & - & - & - & - & - & 1 & 200 & 1.25 \\
\hline S1-400-1.25 & St. P1. & Bot. & - & 43 & - & - & - & - & - & 1 & 400 & 1.25 \\
\hline $\mathrm{S} 1-400-2.5$ & St. P1. & Bot. & - & 43 & - & - & - & - & - & 1 & 400 & 2.5 \\
\hline
\end{tabular}

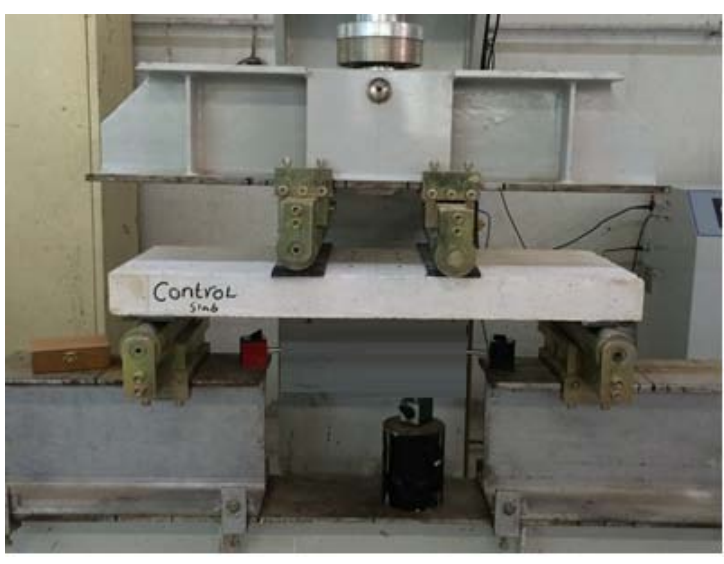

Fig. 7: Test setup

$600 \mathrm{kN}$ universal testing machine. Vertical deflections were recorded at three points: the mid span and $150 \mathrm{~mm}$ to the left and right of the specimen's center line.

\section{RESULTS AND DISCUSSION}

Load deflection relationships: The load deflection relationships of all the tested specimens are presented in Fig. 8. The deflection was recorded at the mid span of the slabs. For all specimens, the load displacement curves identify two stages: linear elastic up to the yielding load $\left(\mathrm{P}_{\mathrm{y}}\right)$ and nonlinear plastic extends from yield to the ultimate strength $\left(\mathrm{P}_{u}\right)$ of the specimens. Accordingly, the behaviour can be simulated using bilinear model. Table 2-5 list the strength, stiffness and ductility for all the tested specimens. The initial stiffness of the specimens was calculated by considering the yield strength and the yield displacement $\left(\mathrm{P}_{\mathrm{y}} / \Delta_{\mathrm{y}}\right)$. The post yield stiffness was calculated from the difference between the ultimate load and the yield load $(\Delta \mathrm{P})$ and the net plastic displacement $\left(\Delta \mathrm{P} / \Delta_{\mathrm{un}}\right)$. The net plastic displacement $\left(\Delta_{\mathrm{un}}\right)$ can be found by taking out the yield displacement $\left(\Delta_{\mathrm{y}}\right)$ from the ultimate displacement $\left(\Delta_{\mathrm{u}}\right)$. For specimens strengthened with overlying concrete, the highest improvement in the strength was obtained from specimens O20SDS40 and O20SDS80. The initial and post yield stiffness improved significantly for all the strengthened specimens and the higher improvement was in specimen O40SDS40 but this specimen fails in brittle manner. In terms of strength, stiffness and ductility specimens $\mathrm{O} 20 \mathrm{~S} 80$ and $\mathrm{O} 20 \mathrm{SCS} 40$ can be consider as the best choice for strengthening using overlying concrete as they show noticeable improvement in the strength and stiffness and the highest ductility among the group.

Specimens strengthened by ferrocement show marginal enhancement in strength and there was no improvement in the specimen's stiffness due to the ferrocement strengthening. The ductility of the specimens shows slight enhancement in specimens F2-40-0, F2-40-1 and F2-20-0 and for the other specimens the ductility was reduced with the strengthening. Therefore, it is recommended to not use the ferrocement in the strengthening on one-way slabs. In CFRP group, the strength shows obvious improvement and the highest strength was recorded for specimen C2-100 whereas, the stiffness did not show sharp increase. Apart from specimen $\mathrm{C} 2-50$, the ductility dropped significantly with the use of CFRP. It can be clearly seen that the optimum performance can be obtained by using two strips of CFRP 
Table 2: Strength, stiffness and ductility for specimens strengthened by overlying concrete

\begin{tabular}{lccccccc}
\hline Specimens & $\mathrm{P}_{\mathrm{v}}(\mathrm{kN})$ & $\Delta_{\mathrm{v}}(\mathrm{mm})$ & $\mathrm{K}_{\mathrm{i}}(\mathrm{kN} / \mathrm{mm})$ & $\mathrm{P}_{\mathrm{u}}(\mathrm{kN})$ & $\Delta_{u}(\mathrm{~mm})$ & $\mathrm{K}_{\mathrm{v}}(\mathrm{kN} / \mathrm{mm})$ & $\mu\left(\Delta_{v} / \Delta_{\mathrm{v}}\right)$ \\
\hline $\mathrm{S}_{0}$ & 70 & 7.00 & 10.00 & 80.00 & 19.3 & 0.813 & 2.757 \\
O20SCS40 & 90 & 5.60 & 16.07 & 113.7 & 28.2 & 1.049 & 5.036 \\
O20SDS80 & 90 & 5.05 & 17.82 & 115 & 24.5 & 1.285 & 4.851 \\
O20OPCS40 & 90 & 4.70 & 19.15 & 98.2 & 7.85 & 2.603 & 1.670 \\
O20WS40 & 100 & 5.40 & 18.52 & 110.2 & 11.2 & 1.759 & 2.074 \\
O20SDS40 & 100 & 5.35 & 18.69 & 115 & 13.3 & 1.887 & 2.486 \\
O40SDS40 & 100 & 4.20 & 23.81 & 110 & 5.75 & 6.452 & 1.369 \\
\hline
\end{tabular}

Table 3: Strength, stiffness and ductility for specimens strengthened by ferrocement

\begin{tabular}{lccccccc} 
Specimens & $\mathrm{P}_{\mathrm{Y}}(\mathrm{kN})$ & $\Delta_{\mathrm{Y}}(\mathrm{mm})$ & $\mathrm{K}_{\mathrm{i}}(\mathrm{kN} / \mathrm{mm})$ & $\mathrm{P}_{\mathrm{u}}(\mathrm{kN})$ & $\Delta_{\mathrm{u}}(\mathrm{mm})$ & $\mathrm{K}_{\mathrm{p}}(\mathrm{kN} / \mathrm{mm})$ & $\mu\left(\Delta_{\mathrm{u}} / \Delta_{\mathrm{Y}}\right)$ \\
\hline $\mathrm{S}_{0}$ & 70 & 7 & 10.00 & 80 & 19.3 & 0.813 & 2.757 \\
F2-40-0 & 73.8 & 7.5 & 9.84 & 88 & 26.2 & 0.759 & 3.493 \\
F2-40-1 & 80 & 8.78 & 9.11 & 89.6 & 28.58 & 0.485 & 3.255 \\
F2-20-0 & 80 & 9.07 & 8.82 & 86.7 & 33.8 & 0.271 & 3.727 \\
F4-20-0 & 80 & 8.8 & 9.09 & 89.6 & 23.5 & 0.653 & 2.670 \\
F2-20-1 & 80 & 8.1 & 9.88 & 87.7 & 17.7 & 0.802 & 2.185 \\
F4-20-1 & 80 & 8.2 & 9.76 & 89.8 & 16.25 & 1.217 \\
\hline
\end{tabular}

Table 4: Strength, stiffness and ductility for specimens strengthened by CFRP

\begin{tabular}{lccccccc}
\hline Specimens & $\mathrm{P}_{\mathrm{V}}(\mathrm{kN})$ & $\Delta_{\mathrm{V}}(\mathrm{mm})$ & $\mathrm{K}_{\mathrm{i}}(\mathrm{kN} / \mathrm{mm})$ & $\mathrm{P}_{\mathrm{u}}(\mathrm{kN})$ & $\Delta_{u}(\mathrm{~mm})$ & $\mathrm{K}_{\mathrm{v}}(\mathrm{kN} / \mathrm{mm})$ & $\mu\left(\Delta_{v} / \Delta_{\mathrm{v}}\right)$ \\
\hline $\mathrm{S}_{0}$ & 70 & 7.00 & 10.00 & 80.0 & 19.30 & 0.813 & 2.757 \\
$\mathrm{C} 2-50$ & 80 & 7.90 & 10.13 & 95.1 & 24.50 & 0.910 & 3.101 \\
$\mathrm{C} 1-100$ & 81 & 8.06 & 10.05 & 89.0 & 13.97 & 1.354 \\
$\mathrm{C} 2-100$ & 95 & 8.83 & 10.76 & 97.5 & 11.65 & 0.887 & 1.733 \\
\hline
\end{tabular}

Table 5: Strength, stiffness and ductility for specimens strengthened by steel plate

\begin{tabular}{llllllll}
\hline Specimens & $\mathrm{P}_{\mathrm{V}}(\mathrm{kN})$ & $\Delta_{\mathrm{y}}(\mathrm{mm})$ & $\mathrm{K}_{\mathrm{i}}(\mathrm{kN} / \mathrm{mm})$ & $\mathrm{P}_{\mathrm{u}}(\mathrm{kN})$ & $\Delta_{\mathrm{u}}(\mathrm{mm})$ & $\mathrm{K}_{\mathrm{p}}(\mathrm{kN} / \mathrm{mm})$ & $\mu\left(\Delta_{\mathrm{u}} / \Delta_{\mathrm{V}}\right)$ \\
$\mathrm{S}_{\mathrm{o}}$ & 70 & 7 & 10.00 & 80 & 19.3 & 0.813 & 2.757 \\
$\mathrm{~S} 1-400-1.25$ & 103.8 & 10 & 10.38 & 120 & 28.5 & 0.876 & 2.850 \\
$\mathrm{~S} 1-200-1.25$ & 100 & 7.55 & 13.25 & 113.2 & 18.7 & 1.184 & 2.477 \\
$\mathrm{~S} 1-400-2.5$ & 160 & 5.05 & 31.68 & 165 & 5.55 & 10.000 & 1.099 \\
\hline
\end{tabular}
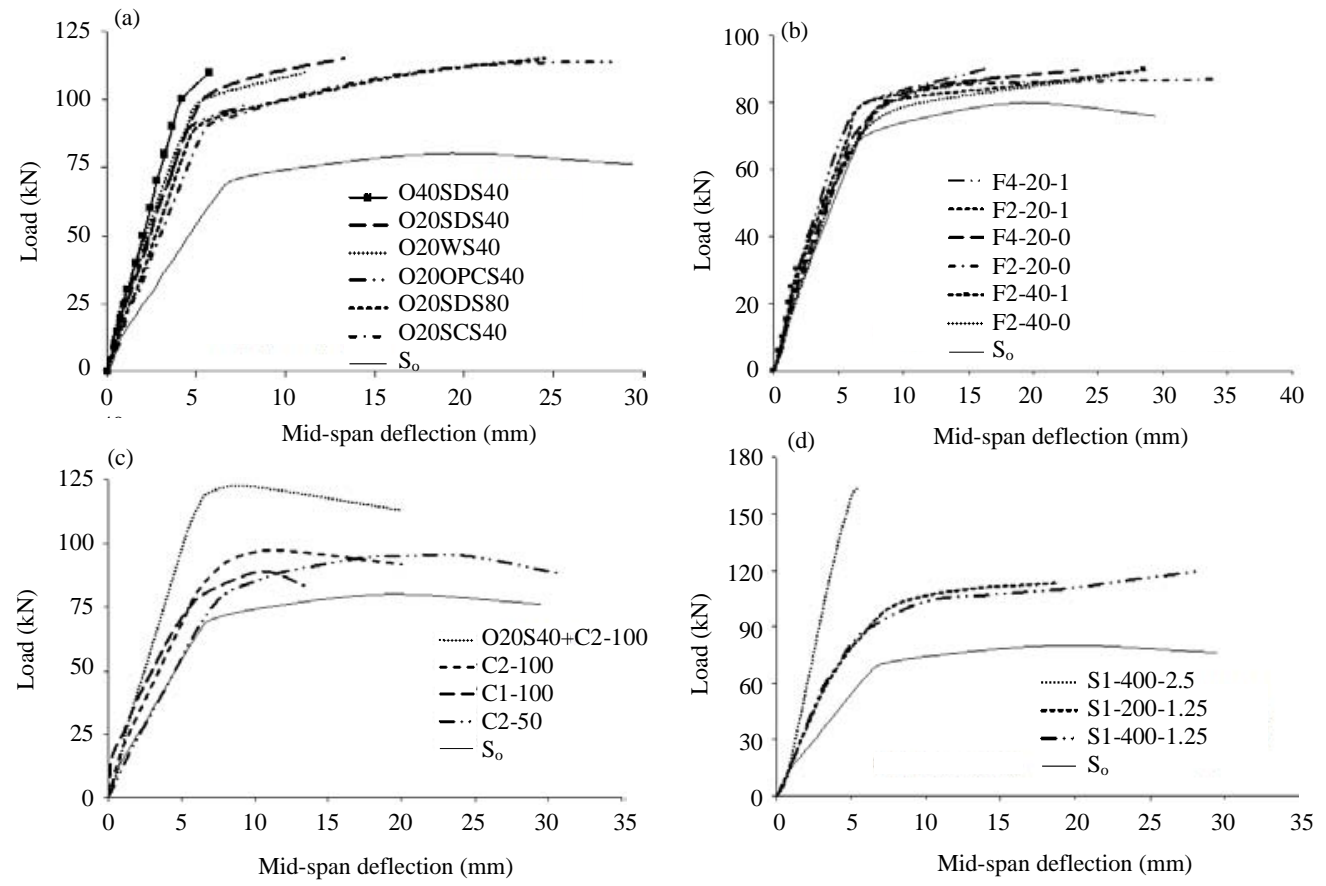

Fig. 8 a, b): Load versus mid-span deflection curves of tested specimens

of width equal to $50 \mathrm{~mm}$ (for each strip) which is equivalent to 0.125 of the slab width (specimen C2-50).
For specimens strengthened with steel plate, the result reveals that there has been a marked increase in strength 
(a)
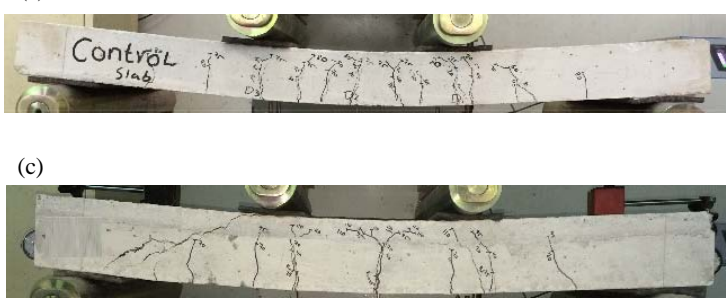

(e)

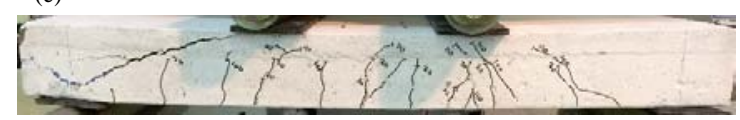

(g)

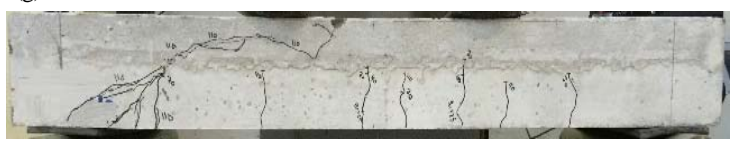

(i)

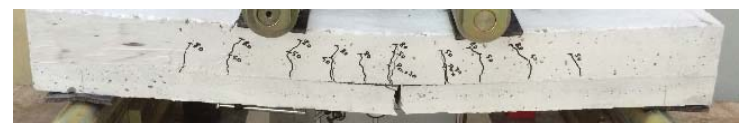

(k)

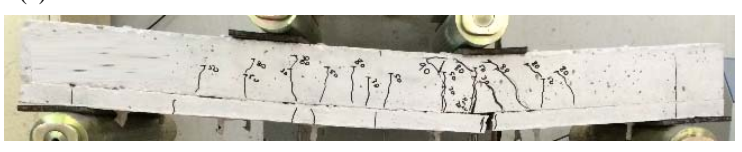

(m)

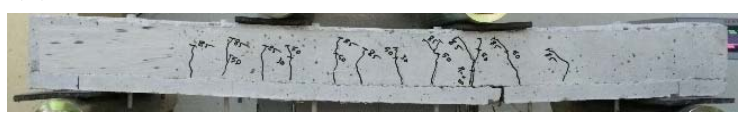

(o)

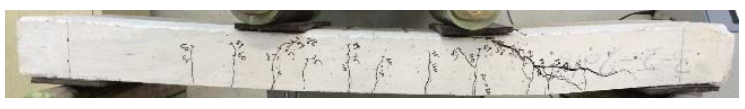

(q)

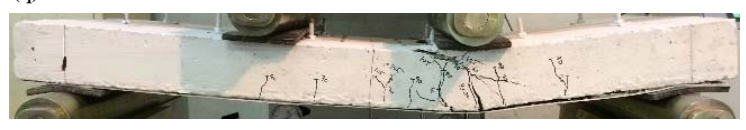

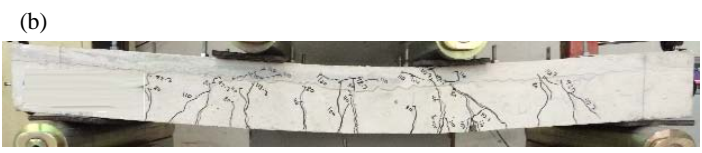

(d)

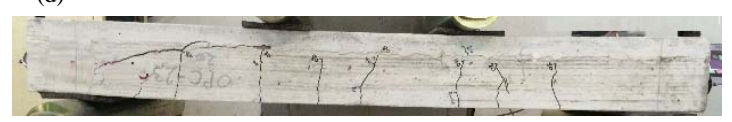

(f)

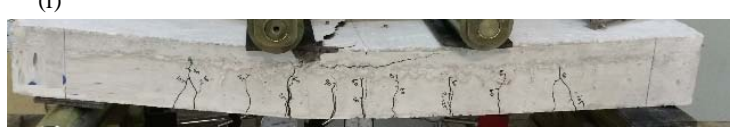

(h)

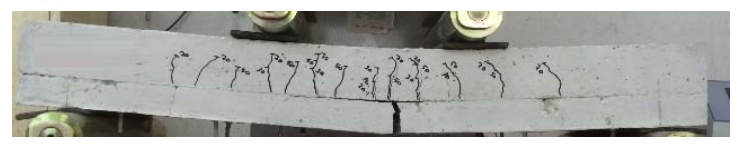

(j)

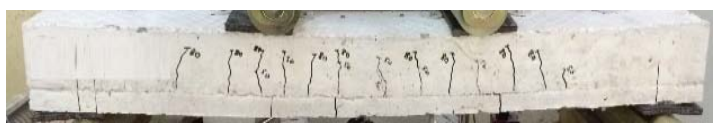

(1)

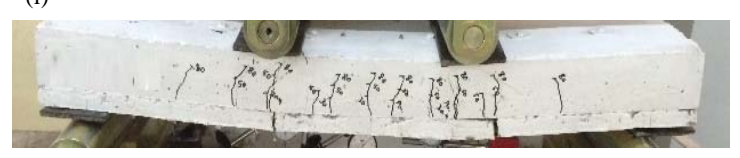

(n)

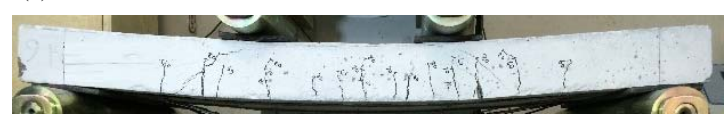

(p)

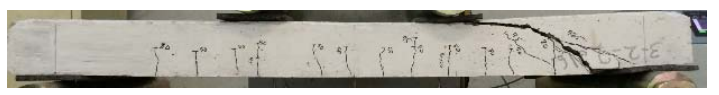

(r)

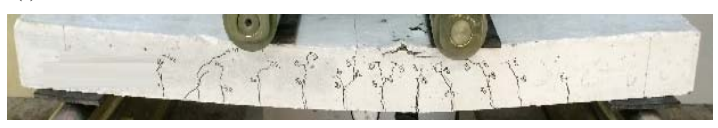

(s)

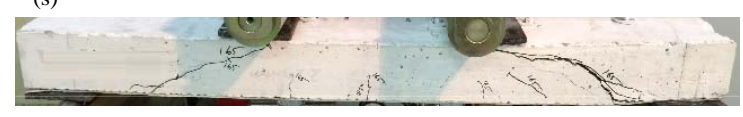

Fig. 9: Failure modes and crack patterns: a) $\mathrm{S}_{0}$ flexural ductile failure; b) O20SCS40 flexural ductile failure; c) O20SDS80 flexural ductile failure; d) O20OPC40 brittle shear failure; e) O20WS40 brittle shear failure; f) O20SDS40 flexural ductile failure; g) O40SDS40 brittle shear failure; h) F2-40-0 flexural ductile failure; i) F2-40-1 flexural ductile failure; j) F2-20-0 flexural ductile failure; k) F4-20-0 flexural ductile failure; 1) F2-20-1 flexural ductile failure; m) F4-20-1 flexural ductile failure; n) C2-50 flexural ductile failure; o) C1-100 brittle shear failure; $\mathrm{p}$ ) C2-100 brittle shear failure; q) S1-400-1.25 flexural ductile failure; r) S1-200-1.25 flexural ductile failure and s) S1-400-2.5 brittle shear failure

and stiffness of the strengthened specimens. Specimen S1-400-2.5 shows clear drop in ductility whereas other specimens express negligible change in ductility Fig. 9. This results indicate that the steel plate should cover the 
Table 6: Cracking load and ultimate load

\begin{tabular}{|c|c|c|c|c|c|}
\hline Specimens & Cracking load $\mathrm{P}_{c}(\mathrm{kN})$ & Ultimate load $\mathrm{P}_{\mathrm{u}}(\mathrm{kN})$ & $\mathrm{P}_{c} / \mathrm{P}_{\mathrm{u}}$ & $\mathrm{P}_{d} / * \mathrm{P}_{c e}$ & $\mathrm{P}_{v} / * \mathrm{P}_{w_{0}}$ \\
\hline $\mathrm{S}_{0}$ & 15.0 & 80.0 & 0.19 & 1.00 & 1.00 \\
\hline $\mathrm{O} 20 \mathrm{SCS} 40$ & 25.0 & 113.2 & 0.22 & 1.67 & 1.42 \\
\hline O20S80 & 25.3 & 115.0 & 0.22 & 1.69 & 1.44 \\
\hline $\mathrm{O} 20 \mathrm{CS} 40$ & 26.0 & 115.0 & 0.23 & 1.73 & 1.44 \\
\hline O20WS40 & 22.0 & 110.2 & 0.20 & 1.47 & 1.38 \\
\hline $\mathrm{O} 20 \mathrm{~S} 40$ & 25.2 & 115.0 & 0.22 & 1.68 & 1.44 \\
\hline O40S40 & 25.0 & 110.0 & 0.23 & 1.67 & 1.38 \\
\hline $\mathrm{F} 2-40-0$ & 20.1 & 88 & 0.23 & 1.34 & 1.10 \\
\hline F2-40-1 & 30.2 & 89.6 & 0.34 & 2.01 & 1.12 \\
\hline $\mathrm{F} 2-20-0$ & 18.3 & 86.7 & 0.21 & 1.22 & 1.08 \\
\hline F4-20-0 & 20 & 89.6 & 0.22 & 1.33 & 1.12 \\
\hline F2-20-1 & 30.4 & 87.7 & 0.35 & 2.03 & 1.10 \\
\hline F4-20-1 & 30 & 89.8 & 0.33 & 2.00 & 1.12 \\
\hline $\mathrm{C} 2-50$ & 17 & 95.1 & 0.18 & 1.13 & 1.19 \\
\hline C1-100 & 17.5 & 89 & 0.20 & 1.17 & 1.11 \\
\hline $\mathrm{C} 2-100$ & 20 & 97.5 & 0.21 & 1.33 & 1.22 \\
\hline S1-400-1.25 & 32 & 120 & 0.27 & 2.13 & 1.50 \\
\hline $\mathrm{S} 1-200-1.25$ & 18 & 113.2 & 0.16 & 1.20 & 1.42 \\
\hline $\mathrm{S} 1-400-2.5$ & 90 & 165 & 0.55 & 6.00 & 2.06 \\
\hline
\end{tabular}

${ }^{*} \mathrm{P}_{\mathrm{co}}$ is the cracking load of the control specimen; ${ }^{* *} \mathrm{P}_{\mathrm{vo}}$ is the ultimate load of the control specimen

whole width of the slab and its thickness must not be more than $t / 64$ where $t$ is the slab thickness because increasing the plate to more than this limits will reduce the slab ductility.

Failure modes: Figure 9 shows the failure modes and the crack pattern of all the tested specimens. The behaviour of all specimens was similar before the existence of any cracks. Two main failure modes were noticed: flexural ductile failure and brittle shear failure. Debonding was recorded only in specimens strengthened by CFRP. The control specimen showed typical ductile failure mode and the behaviour turned into brittle failure with increase of the strength of the strengthening layers. To avoid brittle failure, the stiffness of the strengthening layer should not be more than $1 / 38$ of the stiffness of the strengthened element.

Initial cracking loads and ultimate load: Table 6 lists the initial cracking load and the ultimate load for all specimens. It is clear that both of the initial cracking and the ultimate loads are increased for all the strengthened specimens. However, the amount of increase is related to the strength of the strengthening material. For example, the initial cracking load of specimen S1-400-1.25 is about 2 times of that of control specimen and the initial cracking load of specimen S1-400-2.5 is 6 times of that of control specimen. The difference which is equal to 4 is attributed to doubling the thickness of the steel plate. Another interesting finding is the improvement in the initial cracking load is always higher than that in the ultimate load.

\section{CONCLUSION}

Experimental investigations of the effect of four strengthening techniques (overlaying concrete, ferrocement, CFRP and plates) on the behaviour of one-way reinforced concrete slab were conducted in this study. It was found that, the amount of improvement in the strength and stiffness of the strengthened specimens is related to the stiffness of the strengthening layer. Therefore, to avoid brittle failure it is recommended to limit the stiffness of the strengthening layer to not be more than $1 / 38$ of the stiffness of the strengthened element. In addition to debonding of CFRP layers, two modes of failure modes were observed: flexural ductile failure and brittle shear failure. The improvement in the initial cracking load is always higher than that in the ultimate load. For specimens strengthened by steel plates, the width of the steel plate should be equal to the width of the slab and the thickness of the steel plate must not be more than $t / 64$ where $t$ is the slab thickness, to limit brittle failure possibility. It is recommended to avoid ferrocement in strengthening one-way reinforced concrete slab due to its limited capacity in improving the slab strength and stiffness.

\section{REFERENCES}

Al-Kubaisy, M.A. and M.Z. Jumaat, 2000. Flexural behaviour of reinforced concrete slabs with ferrocement tension zone cover. Constr. Build. Mater., 14: 245-252.

Alam, M.A., W. Mohammed, S. Bakkar and S. Beddu, 2018. Prevention of premature failures of plate bonded flexurally strengthened $\mathrm{RC}$ slab using end anchor and connector. Alexandria Eng. J., 57: 287299. 
Ali, T. and S. Yehia, 2016. Study on strengthening of RC slabs with different innovative techniques. Open J. Civ. Eng., 6: 516-525.

Anil, O., N. Kaya and O. Arslan, 2013. Strengthening of one way RC slab with opening using CFRP strips. Constr. Build. Mater., 48: 883-893.

Correia, L., J. Sena-Cruz, J. Michels, P. Franca and E. Pereira et al., 2017. Durability of RC slabs strengthened with prestressed CFRP laminate strips under different environmental and loading conditions. Compos. Part B. Eng., 125: 71-88.

El Maaddawy, T. and K. Soudki, 2008. Strengthening of reinforced concrete slabs with mechanically-anchored unbonded FRP system. Constr. Build. Mater., 22: 444455.

Erki, M.A. and P.J. Heffernan, 1995. Reinforced concrete slabs externally strengthened with fibre-reinforced plastic materials. RILEM. Proc., 29: 509-516.

Fathelbab, F.A., M.S. Ramadan and A. Al-Tantawy, 2014. Strengthening of RC bridge slabs using CFRP sheets. Alexandria Eng. J., 53: 843-854.

Fernandes, H., V. Lucio and A. Ramos, 2017. Strengthening of RC slabs with reinforced concrete overlay on the tensile face. Eng. Struct., 132: 540-550.

Hor, Y., W. Teo and S. Kazutaka, 2017. Experimental investigation on the behaviour of reinforced concrete slabs strengthened with ultra-high performance concrete. Constr. Build. Mater., 155: 463-474.

Julio, E.N.B.S., D. Dias-da-Costa, F.A.B. Branco and J.M.V. Alfaiate, 2010. Accuracy of design code expressions for estimating longitudinal shear strength of strengthening concrete overlays. Eng. Struct., 32: 2387-2393.
Loreto, G., L. Leardini, D. Arboleda and A. Nanni, 2013. Performance of RC slab-type elements strengthened with fabric-reinforced cementitious-matrix composites. J. Compos. Constr., 18: A4013003A4013003.

Martin, J.A. and A.J. Lamanna, 2008. Performance of mechanically fastened FRP strengthened concrete beams in flexure. J. Compos. Constr., 12: 257-265.

Ngidi, S.D. and M. Dundu, 2018. Composite action of precracked reinforced concrete beams repaired with adhesive bonded steel plates. Struct., 14: 400-408.

Shaheen, Y.B. and H.M. Abusafa, 2017. Structural behavior for rehabilitation ferrocement plates previously damaged by impact loads. Case Stud. Constr. Mater., 6: 72-90.

Smith, S.T. and S.J. Kim, 2009. Strengthening of one-way spanning RC slabs with cutouts using FRP composites. Construct. Build. Mater., 23: 1578-1590.

Smith, S.T., S. Hu, S.J. Kim and R. Seracino, 2011. FRPstrengthened RC slabs anchored with FRP anchors. Eng. Struct., 33: 1075-1087.

Tank, T. and C.D. Modhera, 2017. Finite element modelling of RC slab strengthened with GFRP. Mater. Today Proc., 4: 9784-9791.

Wang, J.W. and K.H. Tan, 2002. Punching shear behaviour of RC flats slabs externally strengthened with FRP systems. Proceedings of the 5th International Symposium on Fibre Reinforced Plastics for Reinforced Concrete Structures (FRPRCS-5) Vol. 2, July 16-18, 2001, Cambridge University, Cambridge, UK., pp: 997-1005.

Yang, J.Q., S.T. Smith, Z. Wang and Y.Y. Lim, 2018. Numerical simulation of FRP-strengthened RC slabs anchored with FRP anchors. Constr. Build. Mater., 172: 735-750. 